\title{
Effect of Irrigation Regimes on Productivity and Water Utilization Efficiency of Three Oil Olive Varieties Under Drip Irrigation System. Abd El-All, A. E. ${ }^{1}$; M. M. attia ${ }^{2}$ and H. El-Zaher ${ }^{1}$ \\ Calcareous and Sand Soil Research Department, ARC, Giza, Egypt ${ }^{1}$ Water Requirements and Field Irrigation Research Department. ARC, Giza, Egypt ${ }^{2}$
}

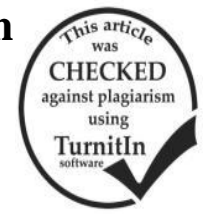

\section{ABSTRACT}

A field experiment was conducted over a period of two successive growing seasons 2011 and 2012 on 14 years old olive trees cultivated in sandy soil located at El-Bostan area in Ali Mubark experimental farm at south Tahrir region to investigate the effect of two different drip irrigation regimes (Traditional irrigation (TI) and deficit irrigation (DI)) on the productivity and water utilization efficiency of three oil olive cultivars (Olea europaea L.), Arbequina, Shamlali and Koroniki. The experimental design was split plot with three replicates (tree) where each tree has four emitters with discharge of 16 (TI) and 12 (DI) L/hr/emitter. Two applied irrigation water amounts (as mean value for two growing seasons) were used 28.61 and $21.46 \mathrm{~m}^{3} /$ tree/year for TI and DI, respectively. The obtained data showed that fresh fruit weight, fruit and oil yield (as mean value for two growing seasons) were significantly decreased when olive trees subjected to deficit irrigation of the three olives varieties. With respect to olive varieties, the highest mean values of fruit weight were obtained from Arbequina variety (1.62 gm) followed by Koroniki (1.32 gm) while the lowest mean fruit weights were obtained with Shamlali $(1.19 \mathrm{gm})$ variety. The percentage of reduction in fruit yield of trees under DI treatment (as mean value for two growing seasons ) were 15.3, 15.1 and $14.2 \%$ as compared to TI regime for Shamlali, Arbequina and Koroniki olive varieties, respectively. The highest mean values of oil percentage (fresh weight basis) were obtained when olive trees subjected to deficit irrigation (DI) and Koroniki variety was the highest in oil percentage (19.52\%). The highest values of water utilization efficiency (WUtE) were 2.73, 2.63 and $2.96 \mathrm{~kg}$ fresh weight fruit $/ \mathrm{m}^{3}$ and were $0.50,0.51$ and $0.60 \mathrm{~kg} \mathrm{oil} / \mathrm{m}^{3}$ under deficit irrigation treatments (DI) (as a mean values of the two growing seasons) for Shamlali, Arbequina and Koroniki olive varieties, respectively.

\section{INTRODUCTION}

Egypt has reached that the quantity of water available limits its national economic development. As indication of water scarcity in absolute terms, Egypt has passed the threshold value of $1000 \mathrm{~m} 3 /$ capita/year already in nineties. As a threshold of absolute scarcity $500 \mathrm{~m} 3 /$ capita/year is used, this will be evident with population predictions for 2025 which will bring Egypt down to value of $500 \mathrm{~m} 3 /$ capita/year (Ministry of Water Resources and Irrigation, Egypt, 2014).

When water quantity is limiting, irrigation management must shift from maximizing production per unit area towards maximizing the production per unit of water used or consumed, the water productivity. Deficit irrigation is an important tool to achieve the goal of reducing irrigation water use, thus increasing water utilization efficiency (WUtE). Crop WUtE is an important consideration where irrigation water resources are limited. Additionally, recent increases in energy prices make many irrigated producers asking how to increase their water productivity. There are many factors affected the amount of applied irrigation water for olive trees such as environmental condition, soil type and olive varieties. Due to high diversity of microclimate, rainfall and soil types of olive growing areas, mean seasonal irrigations may range from $180 \mathrm{~m}^{3} / \mathrm{ha}$ to $2,600 \mathrm{~m}^{3} / \mathrm{ha}$ (Gucci and Tattini 1997). Goldhamer et al., (1993, 1994), in California, applied 8 irrigation regimes on 'Manzanillo' olive trees based on $\mathrm{Kc}$ of between 0.16 and 0.85 resulting in annual water applications of between 232 and $1016 \mathrm{~mm}$. Abdel Nasser and Harhash (2001) reported that the high rate of B fertilization (200g borax/year) at the high level of irrigation $\left(27 \mathrm{~m}^{3} /\right.$ tree/year) resulted in increasing the all of studied olive growth parameters.

Patumi et al., (1999) evaluated the response of olive cvs Kalamata, Ascolana Tenera, and Nocellara del
Belice to four irrigation levels: a rain-fed control (T0) and three treatments (T1, T2 and T3) irrigated daily with an amount of $33 \%, 66 \%$ and $100 \%$, respectively of crop evapotranspiration. They found that irrigation treatments have higher yield than in the rain-fed control. The percent of increases in yield with treatment $\mathrm{T} 1$ in 'Nocellara del Belice' was 200\% compared with the rainfed control and with $\mathrm{T} 2$ in 'Ascolana tenera' and 'Kalamata' the yield was $233 \%$ and $47 \%$ greater than in the control, respectively. The higher oil yield obtained in the irrigated treatments was mainly due to the increase in fruit yield.

Regulated deficit irrigation (RDI) is a good strategy to save water without major effects on yield (Chalmers et al., 1981) but this approach requires precise knowledge of the crop response to water stress at different physiological growth stages to identify the periods when fruit trees are less sensitive (Fereres and Goldhamer, 1990). In olive trees, water stress in the early growth stages may reduce the yield due to effects on flowering and fruit set (Orgaz and Fereres, 2004).The most resistant to water deficit was occurred at pit hardening in the second phase of fruit development (Goldhamer, 1999). Moriana et al., (2003) compared deficit irrigated trees under continuous deficit irrigation (CDI) and regulated deficit irrigation (RDI) to fully irrigated trees and found that continuous deficit irrigation (CDI) and regulated deficit irrigation (RDI) strategies reduced the ET and consequently the yield and reported that the water use efficiency (WUE) is reduced when the amount of irrigation increases but definitive conclusions on the performance of the two strategies cannot be drawn because ET was different in both deficit irrigation strategies due to different amounts of irrigation applied in CDI and RDI. Iniesta et al., (2009) found that both deficit irrigation strategies, CDI and RDI, caused a higher reduction in olive fruit yield than oil yield due to a higher oil concentration in deficit 
irrigated trees, without differences between CDI and RDI. Therefore, both irrigation strategies can be used to save a significant amount of irrigation in olive with moderate reductions in oil yield. Lavee et al., (1990) found that irrigated olive trees with $75-200 \mathrm{~mm}$ in one to three irrigations were effective in increasing yields over rain-fed olives. Another study by Beede and Goldhamer (1994) indicated that mature olive trees irrigated with less than $777 \mathrm{~mm}$ were still under water stress. On the other hand, Baratta et al., (1986) found that irrigated olive trees with $800-1000 \mathrm{~mm}$ in season was needed to obtain maximum yield. Also, Zelek et al., (2012) investigated the effect of three irrigation regimes, rainfed, $\mathrm{R}(0 \% \mathrm{ETc})$; deficit, $\mathrm{D}(50 \% \mathrm{ETc})$; and irrigated, I (100\% ETc) on olive oil content and physical quality parameters of fruits and reported that both D (50\% ETc) and I (100\% ETc) increase the fruit size of three of the varieties, but had no effect on oil contents compared to rainfed, R $(0 \%$ ETc) while irrigation water saving was $35 \%$ for rainfed, $\mathrm{R}(0 \%$ ETc) treatments compared with the I treatment and the $\mathrm{D}$ treatment which resulted in $17.5 \%$ water saving with minor effects on fruit size, timing of maturity and oil content. In Spain, Alegre et al., (2000) studied the effect of different irrigation regimes $(75 \%, 50 \%$ and $0 \%$ of ETc) on the yield of the Arbequina cultivar from pit hardening to the beginning of fruit ripening and reported that there is no significant reductions in olive yield.

Many studies has investigated the effect of different strategies of deficit irrigation on olive fruit yield and oil yield and suggested the need for calibrating RDI for each cultivar-environment combination (Goldhamer et al., 1994; Patumi et al., 1999; Tognetti et al. 2006). Anther investigators have shown that irrigation can increase olive fruit yield production (Samish and Spiegel, 1961; Lavee et al., 1990; Moriana et al., 2003) thereby increasing total oil production per tree. Mitchell and Chalmers (1982) reported that WUtE, expressed as yield per unit applied irrigation water, increased from 4.9 to $8.0 \mathrm{t} / \mathrm{ML}$ under RDI in peaches that yielded $48 \mathrm{t} / \mathrm{ha}$. Goldhamer (1999) reported water savings of $25 \%$ for RDI applied to olives trees in California, United States of America, with no reduction in olive fruit yield. Increased WUtE under RDI is due largely to reductions in transpiration, which might be as much as 50 percent (Boland et al., 1993b)

Deficit irrigation is a good tool to increase water saving which resulted in increasing water utilization use efficiency (WUtE). Thereby the objective of this study was to investigate the effect of two different irrigation regime: 1- Traditional irrigation (TI) and 2- Deficit irrigation (DI) on the fruit fresh weight, olive fruit yield, oil percentage, oil yield and water utilization efficiency (WUtE) for three different oil olive cultivars (Shamlali, Koroniki and Arbequina) in sandy soil under drip irrigation system at south El-Tahrir, El-Bostan region.

\section{MATERIALS AND METHODS}

\section{Field experimental site:}

Field experiment was conducted in sandy soil under drip irrigation system at El-Bostan area in Aly Mubark experimental farm at south Tahrir region during 2011 and 2012 growing seasons to study the effect of two different irrigation regimes traditional irrigation (TI) which the olive trees received $22.23 \mathrm{~m}^{3} /$ tree/year and about $16.67 \mathrm{~m}^{3} /$ tree/year under deficit irrigation (DI) treatments as a mean values of two growing seasons on the productivity and water utilization (WUtE) of three oil olive cultivars Shamlali, Koroniki and Arbequina. The source of irrigation water were deep well and Nile water according its availability. Soil physical and chemical properties of the experimental site were analyzed according to Jackson, (1973) and Page et. al., (1982) and presented in Tables 1 and 2.

Table 1. Soil physical properties of experimental site

\begin{tabular}{lcccccccc}
\hline Soil depth, cm & F.C\% & W.P\%* & A.W \%* & BD, $\mathbf{~ g m c m}^{-3}$ & \multicolumn{2}{c}{ Particle size distribution, \% } & \multicolumn{2}{c}{ Soil texture } \\
sand & silt & clay & class \\
\hline $0-30$ & 12.1 & 5.4 & 6.7 & 1.55 & 92.9 & 2.7 & 4.4 & Sandy \\
$30-60$ & 11.9 & 5.1 & 6.8 & 1.60 & 91.3 & 4.6 & 4.1 & Sandy \\
60-90 & 10.4 & 4.2 & 6.2 & 1.62 & 90.5 & 5.6 & 3.9 & sandy \\
\hline
\end{tabular}

*On weight basis

Table 2. Soil chemical properties of experimental site

\begin{tabular}{|c|c|c|c|c|c|c|c|c|c|c|}
\hline Soil depth, cm & $E C^{1}, d S / m$ & $\mathrm{pH}^{2}$ & $\mathrm{Cr}^{++}$ & & Solub & ations & id anio & meq/L). & & \\
\hline $0-30$ & 0.37 & 8.6 & $\frac{\mathbf{C a}}{1.20}$ & $\frac{\mathbf{l n g}}{0.65}$ & $\frac{\mathrm{Na}}{1.60}$ & $\frac{\mathbf{K}^{+}}{02}$ & $\mathrm{CO}_{3}$ & $\mathrm{HCO}_{3}^{-}$ & $\frac{\mathrm{SO}_{4}^{--}}{0.64}$ & $\frac{\mathrm{Cl}}{10}$ \\
\hline $30-60$ & 0.33 & $\begin{array}{l}0.0 \\
8.8\end{array}$ & 1.15 & 0.50 & 1.40 & 0.21 & --- & 1.03 & 0.52 & 1.7 \\
\hline $60-90$ & 0.38 & 8.8 & 1.20 & 0.53 & 1.80 & 0.22 & ----- & 1.12 & 0.55 & 2.1 \\
\hline
\end{tabular}

1-EC in soil past

2- pH in Soil:water extract (1:2.5)

\section{Experimental treatments:}

Field experimental in spilt plot design with three trees as a one replicate was used. The main plots were the olive cultivars while the sub plots were the irrigation treatments. The oil olive cultivars were Shamlali, Koroniki and Arbequina (14 year old trees) in high density olive orchard $\left(6 * 6 \mathrm{~m}^{2}\right.$, total number of trees per Feddan equal 116 trees). Irrigation treatments were Traditional irrigation (TI) where each tree has four emitters with discharge of $16 \mathrm{l} / \mathrm{hr} / \mathrm{emitter}$ which are traditionally used in El-Bostan area and deficit irrigation (DI) where each tree has four emitters with discharge of $12 \mathrm{l} / \mathrm{hr} / \mathrm{emitter}$. Irrigation treatments were performed for $3 \mathrm{hr} /$ two days at the summer and Autumn seasons and were $3 \mathrm{hr} /$ four days at the winter and spring seasons. Mineral and organic fertilizer and other field practices are done as recommended by Horticulture Crop Research Institute, Agriculture Research Center.

Total yield per tree was measured at harvesting time (the second week of November), a representative 
sample of $2 \mathrm{~kg}$ of fruit per tree was taken to determine fruit characteristics (fruit weight, Fruit oil content). Oil percent was determined according to A.O.A.C (1995). Oil yield $(\mathrm{kg} /$ tree $)$ was calculated as follows.

Oil yield $(\mathrm{Kg} /$ tree $)=$ Oil \% x fruit yield $(\mathrm{Kg} /$ tree $)$.

Water Utilization Efficiency (WUtE):

Water utilization efficiencies were calculated according to Jensen (1983) as follows:

WUtE=olive fruit yield $(\mathrm{kg} / \mathrm{fed}) /$ Applied irrigation water $(\mathrm{m} 3 / \mathrm{fed})$

$\mathrm{WUtE}=$ olive oil yield $(\mathrm{kg} / \mathrm{fed}) /$ Applied irrigation water (m3/fed)

The obtained data were statistically analyzed using statistical package (CoHort, 1986). The mean values for the three replicates of each treatment were interpreted using the analysis of variance (ANOVA). The Duncan's Multiple Range Test was used for comparisons between different sources of variance according to Steel and Torrie (1984).

\section{RESULTS AND DISCUSSION}

\section{Applied irrigation water:}

Actual applied irrigation water for each irrigation event are measured and the actual amount of total applied irrigation water for Traditional irrigation (TI) and deficit irrigation (DI) were calculated and illustrated in Table 3. It is clear that the total applied irrigation water for (TI) treatment was $28.61 \mathrm{~m}^{3} /$ tree/year for the two growing seasons while the illustrated total applied irrigation water for (DI) treatment was 21.46 $\mathrm{m}^{3} /$ tree/year for the two growing seasons (Table 3).

Table 3. Amount of applied irrigation water (AIW) in $\mathrm{m}^{3} /$ tree/month for the three olive cultivars under Traditional irrigation (TI) and deficit irrigation (DI) for 2011and 2012 growing seasons.

\begin{tabular}{|c|c|c|c|c|}
\hline \multirow{3}{*}{ Month } & \multicolumn{4}{|c|}{ Applied irrigation water } \\
\hline & & & & \\
\hline & TI & DI & TI & DI \\
\hline January & 1.92 & 1.44 & 1.92 & 1.44 \\
\hline February & 1.73 & 1.30 & 1.73 & 1.30 \\
\hline March & 1.92 & 1.44 & 1.92 & 1.44 \\
\hline April & 1.92 & 1.44 & 1.92 & 1.44 \\
\hline May & 2.88 & 2.16 & 2.88 & 2.16 \\
\hline June & 2.88 & 2.16 & 2.88 & 2.16 \\
\hline July & 2.88 & 2.16 & 2.88 & 2.16 \\
\hline Augusts & 2.88 & 2.16 & 2.88 & 2.16 \\
\hline September & 2.88 & 2.16 & 2.88 & 2.16 \\
\hline October & 2.88 & 2.16 & 2.88 & 2.16 \\
\hline November & 1.92 & 1.44 & 1.92 & 1.44 \\
\hline December & 1.92 & 1.44 & 1.92 & 1.44 \\
\hline Total $\left(\mathrm{m}^{3} /\right.$ tree/year $)$ & 28.61 & 21.46 & 28.61 & 21.46 \\
\hline Applied irrigation water $\left(\mathrm{m}^{3} /\right.$ feddan/year $)$ & 3318.8 & 2489.1 & 3318.8 & 2489.1 \\
\hline
\end{tabular}

The maximum rate of applied irrigation water applied were during Summer and Autumn seasons and declined during Winter and Spring seasons. These results are agreed with Abdel- Nasser and Harhash (2001), Beede and Goldhamer (1994) and Barratla et. al., (1986).

Fresh fruit weight, oil percentage, fruit and oil yield

Data in Table 4 showed that the mean values of fresh fruit weight, fruit yield, oil percentage (fresh weight basis) and oil yield of the three olive varieties as affected by irrigation regime during 2011 and 2012 growing season. It is clear that, all studied parameters were significantly decreased with decreasing applied irrigation water except oil percentage of the three varieties, the highest mean values of fruit weight were obtained from trees with TI treatments and the fruit weight significantly decreased with DI treatments. With respect to olive varieties, the highest values of fruit weight were obtained from Arbequina varieties followed by Koroniki while the lowest fruit weights were obtained with Shamlali variety. The highest mean values of fruit yield were 75.00, 69.62 and 67.33 $\mathrm{kg} /$ fruit/tree for Koroniki, Shamlali and Arbequina olive varieties, respectively during the first season. Whereas during the second season, the highest mean values were $73.00,68.67$ and $65.33 \mathrm{~kg} /$ tree for the same varieties, respectively. These highest values of fruit yield were obtained from trees with TI treatments. Increasing the amount of applied irrigation water has been reported to increase olive fruit yield (Samish and Spiegel, 1961, Patumi et al., 1999, Grattan et al., 2006, lniesta et al., 2009). The same trend was observed in oil yield. Many studies showed that olive oil percentage were increased with deficit irrigation than traditional irrigation (Lavee et al., 1990, Goldhamer et al., 1994 and Tognetti et al., 2006).

The percentage of reduction in fruit yield of tree under DI treatment were $15.7,15.8$ and $14.2 \%$ for Shamlali, Arbequina and Koroniki olive varieties, respectively during the first growing season whereas during the second growing season, the percentages of reduction in fruit yield were 15.1, 14.3 and $14.2 \%$ for the same varieties, respectively.

The highest values of oil percentage (fresh weight basis) were obtained from trees under DI treatments. With respect to olive varieties, the highest values of oil percentage were obtained from Koroniki variety. Similar results have been reported by Greven et al., (2009) and Melgar et al., (2008) where, they reported that the higher oil yield in rain-fed olive trees is thought to be coupled with lower water contents in fruits of the olive trees, respect to irrigated ones. 
Table 4. Fruit weight (g), fruit yield (kg/tree), oil percentage (\%), and oil yield $\mathrm{kg} / \mathrm{tree}$ for Shamlali, Arbequina and Koroniki olive varieties as affected by irrigation regimes during the two growing seasons 2011 and 2012.

\begin{tabular}{|c|c|c|c|c|c|c|c|c|c|}
\hline \multirow{2}{*}{$\begin{array}{l}\text { Irrigation } \\
\text { regime }\end{array}$} & \multirow[b]{2}{*}{ varieties } & \multicolumn{4}{|c|}{2011} & \multicolumn{4}{|c|}{2012} \\
\hline & & $\begin{array}{c}\text { Fruit } \\
\text { weight }\end{array}$ & Fruit yield & Oil, \% & Oil yield & $\begin{array}{c}\text { Fruit } \\
\text { weight }\end{array}$ & Fruit yield & Oil, \% & Oil yield \\
\hline \multirow{3}{*}{$\begin{array}{l}\text { Traditional } \\
\text { irrigation (TI) }\end{array}$} & Shamlali & 1.28 & 69.62 & 17.20 & 11.93 & 1.29 & 68.67 & 17.40 & 11.96 \\
\hline & Arbequina & 1.67 & 67.33 & 18.63 & 12.53 & 1.80 & 65.33 & 17.90 & 11.70 \\
\hline & Koroniki & 1.40 & 75.00 & 19.33 & 14.50 & 1.54 & 73.00 & 18.37 & 13.40 \\
\hline \multicolumn{2}{|l|}{ Mean of TI } & $1.45 \mathrm{a}$ & $70.65 a$ & $18.39 \mathrm{a}$ & $12.99 \mathrm{a}$ & $1.54 \mathrm{a}$ & $69.00 \mathrm{a}$ & 17.90 & $12.35 \mathrm{a}$ \\
\hline Deficit & Shamlali & 1.13 & 58.67 & 18.23 & 10.73 & 1.06 & 58.33 & 18.57 & 10.88 \\
\hline irrigation & Arbequina & 1.46 & 56.67 & 19.87 & 11.29 & 1.523 & 56.00 & 19.03 & 10.58 \\
\hline (DI) & Koroniki & 1.23 & 64.33 & 20.63 & 13.31 & 1.30 & 62.67 & 19.73 & 12.38 \\
\hline \multicolumn{2}{|l|}{ Mean of DI } & $1.28 \mathrm{~b}$ & $59.89 \mathrm{~b}$ & $19.58 \mathrm{a}$ & $11.77 \mathrm{a}$ & $1.30 \mathrm{~b}$ & $59.00 \mathrm{~b}$ & $19.11 \mathrm{a}$ & $11.28 \mathrm{~b}$ \\
\hline \multirow{3}{*}{$\begin{array}{l}\text { Mean } \\
\text { varieties }\end{array}$} & Shamlali & $1.21 \mathrm{~b}$ & $64.00 \mathrm{ab}$ & $17.72 b$ & $11.33 \mathrm{~b}$ & $1.18 \mathrm{c}$ & $63.50 \mathrm{ab}$ & $17.98 b$ & $11.42 \mathrm{~b}$ \\
\hline & Arbequina & $1.57 \mathrm{a}$ & $62.00 \mathrm{~b}$ & $19.25 \mathrm{a}$ & $11.91 \mathrm{~b}$ & $1.67 \mathrm{a}$ & $60.67 b$ & $18.47 \mathrm{a}$ & $11.14 \mathrm{~b}$ \\
\hline & Koroniki & $1.32 \mathrm{~b}$ & $69.76 \mathrm{a}$ & $19.98 \mathrm{a}$ & $13.90 \mathrm{a}$ & $1.42 \mathrm{~b}$ & $67.83 \mathrm{a}$ & $19.05 \mathrm{a}$ & $12.89 \mathrm{a}$ \\
\hline \multicolumn{2}{|c|}{ LSD0.05 for varieties } & 0.18 & 5.80 & 1.45 & 1.69 & 0.17 & 5.94 & 0.87 & 1.11 \\
\hline \multicolumn{2}{|c|}{ LSD0.05 for irrigation } & 0.14 & 4.74 & 1.18 & 1.38 & 0.14 & 4.85 & 0.71 & 0.96 \\
\hline
\end{tabular}

Water utilization use efficiency (WUtE):

Table 5 shows water utilization efficiency (WUtE) for Shamlali, Arbequina and Koroniki olive varieties as affect by irrigation regimes during the two growing seasons 2011 and 2012 expressed as fruit or oil yield per cubic meter of applied irrigation water. Data showed that the highest values of WUtE for the first growing season under DI treatments were 3.523, 3.403 and $3.863 \mathrm{~kg}$ fresh weight fruit $/ \mathrm{m}^{3}$ and were 0.644 ,
0.678 and $0.799 \mathrm{~kg}$ oil per cubic meter of applied irrigation water for Shamlali, Arbequina and Koroniki olive varieties, respectively. With respect to olive varieties the highest values of WUtE were recorded by Koroniki variety, the same trend was observed for the second growing season. Many studies reported that deficit irrigation increased WUtE for many fruit trees (Mitchell and Chalmers 1982, Goodwin et al., 1998, Boland et al., 1993b, and Goldhamer 1999).

Table 5. Water utilization efficiency (WUtE) for Shamlali, Arbequina and Koroniki olive varieties as affect by irrigation regimes during the two growing season 2011 and 2012.

\begin{tabular}{|c|c|c|c|c|c|c|}
\hline Irrigation regime & varieties & $\begin{array}{l}\text { Applied irrigation } \\
\text { water , } \mathrm{m}^{3} \text { /fed }\end{array}$ & $\begin{array}{c}\text { Fruit yield, } \\
\text { kg/fed }\end{array}$ & $\begin{array}{c}\text { Oil yield, } \\
\text { kg/fed }\end{array}$ & Kg fruit $/ \mathrm{m}^{\mathrm{W}}$ & KE oil/mo \\
\hline \multicolumn{7}{|c|}{ First growing season, 2011} \\
\hline \multirow{4}{*}{ Traditional irrigation (TI) } & Shamlali & 3318.8 & 8075.92 & 1383.88 & 2.43 & 0.42 \\
\hline & Arbequina & 3318.8 & 7810.28 & 1453.48 & 2.35 & 0.44 \\
\hline & Koroniki & 3318.8 & 8700.00 & 1682.00 & 2.62 & 0.51 \\
\hline & Shamlali & 2489.1 & 6805.72 & 1244.68 & 2.73 & 0.49 \\
\hline \multirow[t]{2}{*}{ Deficit irrigation (DI) } & Arbequina & 2489.1 & 6573.72 & 1309.64 & 2.64 & 0.53 \\
\hline & Koroniki & 2489.1 & 7462.28 & 1543.96 & 2.99 & 0.62 \\
\hline \multirow{4}{*}{ Traditional irrigation (TI) } & & Second growin & season, 2012 & & & \\
\hline & Shamlali & 3318.8 & 7965.72 & 1387.36 & 2.40 & 0.42 \\
\hline & Arbequina & 3318.8 & 7578.28 & 1357.20 & 2.28 & 0.41 \\
\hline & Koroniki & 3318.8 & 8468.00 & 1554.40 & 2.55 & 0.47 \\
\hline \multirow{3}{*}{ Deficit irrigation (DI) } & Shamlali & 2489.1 & 6766.28 & 1262.08 & 2.72 & 0.51 \\
\hline & Arbequina & 2489.1 & 6496.00 & 1227.28 & 2.61 & 0.49 \\
\hline & Koroniki & 2489.1 & 7269.72 & 1436.08 & 2.92 & 0.58 \\
\hline
\end{tabular}

\section{REFERENCES}

Abdel-Nasser, G. and M. M. Harhash (2001). Response of Manzanillo olive cultivar to irrigation regime and boron fertigation under Siwa Oasis conditions. I. Vegetative growth and leaf constituents. Conference of Sustainable Agricultural Development, Fayoum Faculty of Agriculture, Cairo University. pp 305-318.

Alegre, S., J., Marsal, M., Mata, A., Arbonés, J., Girona and M., Tovar (2000). Regulated deficit irrigation in olive trees (Olea europaea L. cv. Arbequina) for oil production. In: IV International Symposium on Olive Growing, vol. 586, pp. 259-262.

A.O.A.C. 1995. Association of Official Agriculture Chemists. Official and Methods of Analysis. The A.O.A.C. 15 . Washington, D.C. U.S.A

Baratta, B., T., Caruso, L., Di Marco and P., Inglese (1986). Effects of irrigation on characteristics of olives in 'Nocellara del Belice' variety. Olea 17, 195-198.

Beede, R.H. and D.A.Goldhamer (1994). Olive irrigation management. In: Ferguson, L., G.S.Sibbett, and G.C.Martin (Eds.), Olive Production Manual.University of California Publication 3353, pp. 61-68.
Boland, A.M., P.D.Mitchell, P.H. Jerie, and I. Goodwin (1993b). The effect of regulated deficit irrigation on tree water use and growth of peach. Journal of Horticultural Science 68: 261-274.

CoHort Software. (1986). Costat Statistical package (version 3.03), Berkeley, CA, USA.

Fereres, E., D. Goldhamer (1990). Irrigation of deciduous fruit and nut trees. In: Irrigation of Agricultural Crops. ASA Monograph No. 30. American Society of Agronomy, Madison, WI, pp. $987-1017$.

Gee, G.W. and J.W. Bauder (1986). Particle Size Analysis in Method of Soil Analysis. Klute, Ed, Part1, Agron. Madison, Wisconsin, USA.

Goldhamer, D.A., J. Dunai and L. Ferguson (1993). Water use requirements of Manzanillo olives and responses to sustained deficit irrigation. Acta Hort. 335, 365-371.

Goldhamer, D., J. Dunai and L. Ferguson (1994). Irrigation requirements of olive trees and responses to sustained deficit irrigation. Acta Horticulturae 356: 172-176.

Goldhamer, D. A. (1999). Regulated deficit irrigation for California canning olives. Acta Horticulturae, 474, 369-372. 
Goodwin, I., P.H. Jerie and A.M. Boland (1998). Water saving techniques for orchards in Northern China. In: Water is Gold, Irrigation Association of Australia 1998 National Conference and Exhibition, Brisbane, 19-21 May 1998. Brisbane, Australia, Department of Natural Resources.

Gucci, R. and M.Tattini, (1997). Salinity tolerance in olive. Horticultural Reviews 21: 177-214.

Greven,M., N.Sue, G.Steve, D.Bartolomeo and C.Brent. (2009). The effect of drought on the water use, fruit development and oil yield from young olive trees. Agriculture water management 96:15251531.

Iniesta, F., L. Testi, F. Orgaz and F.J. Villalobos (2009). The effects of regulated and continuous deficit irrigation on the water use, growth and yield of olive trees. Europ. J. Agronomy 30 (2009) 258-265

Jackson, M.L. (1973). Soil Chemical Analysis, Prentice Hall, Inc. Englewood Cliffs, N.J.

Jensen, M.E. (1983). Design and Operation of Farm Irrigation Systems. American Society Agricultural Engineering, St. Joseph, USA, Pp. 827.

Lavee, S. and M.Wodner (1991). Factors affecting the nature of oil accumulation in fruit of olive (Olea europaea L.) cultivars. J.Hort. Sci. 66, 583-591.

Lavee, S., M. Nashef, M.Wodner and H.Harshemesh (1990). The effect of complementary irrigation added to old olive trees (Olea europaea L.) cv. Souri on fruit characteristics, yield and oil production. Advances in Horticultural Science 4, $135-138$.

Melgar.J.C., Y.Mohamed, C.Navarro, M.A.Parra, and M. Benlloch (2008). Long-term growth and yield response of olive trees to different irrigation regimes. Agricuiture water management 95:968972.

Ministry of Water Resources and Irrigation, Egypt. 2014. Water Scarcity in Egypt: The Urgent Need for Regional Cooperation among the Nile Basin Countries. http://www.mfa.gov.eg/Site Collection Documents/Egypt\%20Water\%20Resources\%20P aper_2014.pdf

Mitchell, P.D. and D.J. Chalmers (1982). The effect of reduced water supply on peach tree growth and yields. Journal of the American Society for Horticultural Science 107:853-856.
Moriana, A., Orgaz, F., Fereres, E., Pastor, M., 2003. Yield responses of a mature olive orchard to water deficits. J. Am. Soc. Hort.Sci.128,425-431.

Orgaz, F., Fereres, E., 2004. Riego. In: Barranco, D., Fernández-Escobar, R., Rallo, L. (Eds.), El cultivo del olivo. Mundi Prensa, Madrid, pp. 323 346.

Page, A.L., R.H. Miller and D.R.Keeny (1982). Method of Soil Analysis. Part 2-chemical and microbiological properties second Edition Amer.Soc. of Agron. Madison, Wisconsin, USA.

Patumi M. , R. D’Andria, G. Fontanazza, G. Morelli, P. Giorio and G. Sorrentino. (1999). Yield and oil quality of intensively trained trees of three cultivars of olive (Olea europaea L.) under different irrigation regimes. The Journal of Horticultural Science and Biotechnology. Vol. 74(6)- P 729-737.

Samish, R. and P., Spiegel (1961). The use of irrigation in growing olives for oil production. Israel Journal of Agricultural Research 11, 87-95.

Steel, R.G. and T.H. Torrie. (1984). Principals and Procedures of Statistics. McGrow Hill, Now York, USA.

Tognetti, R., R., d'Andria, A., Lavini and G., Morelli, (2006). The effect of deficit irrigation on crop yield and vegetative development of Olea europaea L. (cvs. Frantoio and Leccino). Eur. J. Agron. 25, 356-364.

Zelak, K., R., Mailerb, P., Eberbacha and J Wu Nsche. (2012). Oil content and fruit quality of nine olive (Olea europaea L.) varieties affected by irrigation and harvesting times. New Zealand Journal of crop and Horticulture Science. Vol.40, NO. 4:241252. http://dx.doi.org/10.1080/ 01140671. 2012.662159

تأثير معدلات مختلفة من الرى على إنتاجية وكفاعة إستخدام المياه لثلاثة أصناف من الزيتون تحت نظام الرى بالتنقيط إلتا

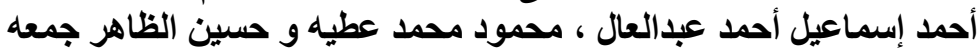

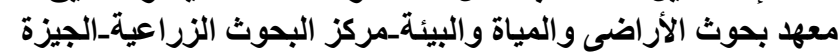

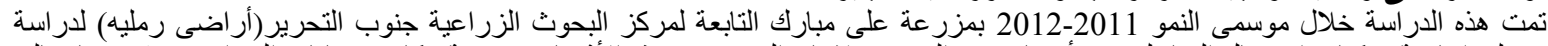

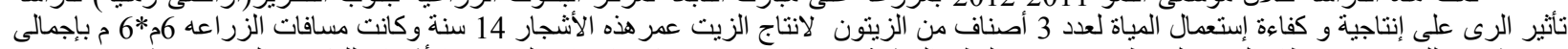

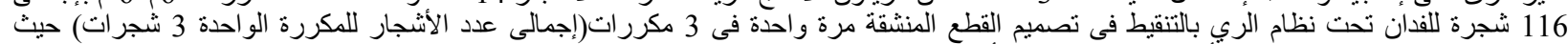

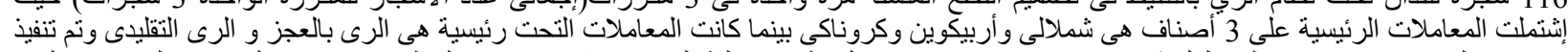

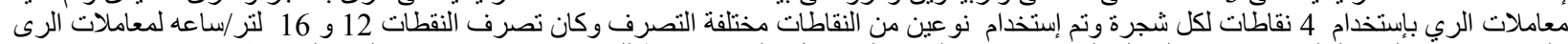

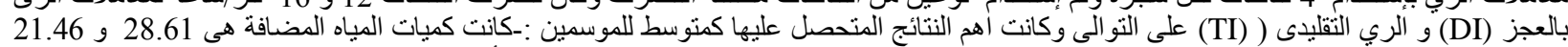

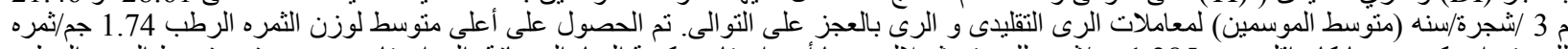

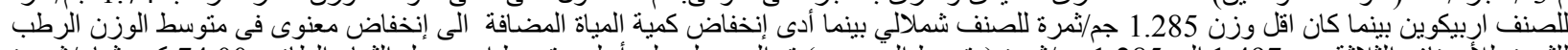

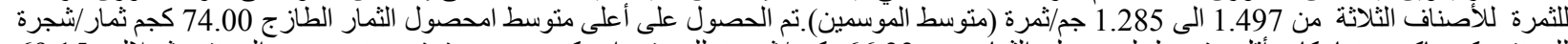

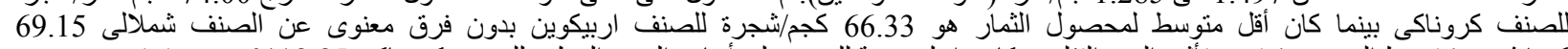

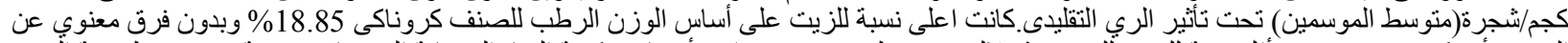

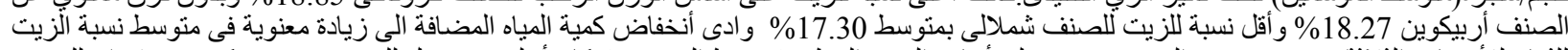

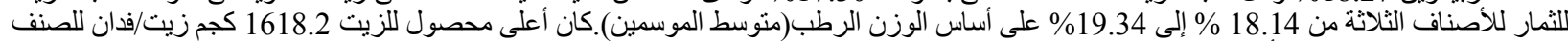

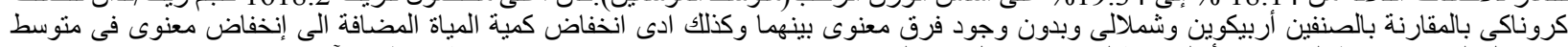

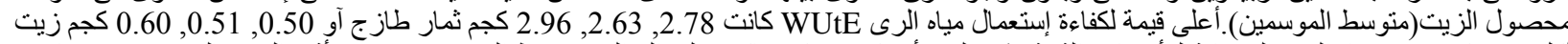

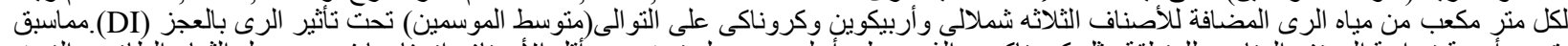

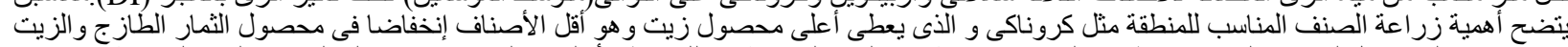

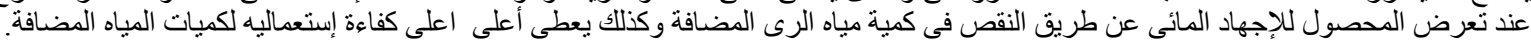

